disposition; the third type - by the unemployed with a low level of internal and professional personal disposition; the fourth type - by the unemployed with low level semantic personal disposition. It is assumed that the content-procedural and effective parameters of overcoming the crisis of employment by the unemployed will be determined primarily by typological features of their personal structure.

Key words: personality, unemployment, overcoming, personal factor, internal personal disposition, semantic personal disposition, professional personality disposition, typology, type of unemployed.

\title{
ПСИХОЛОГІЧНИЙ АНАЛІЗ СОЦАЛЬНОЇ УСТАНОВКИ ДО ІНВАЛІДИЗОВАНИХ ЛЮДЕЙ В ДЕМОГРАФІЧНІЙ ПЛОЩИНІ
}

Стаття присвячена психологічному аналізу існуючої в сучасному соціумі установки стосовно інвалідизованих ї̈ членів. На матеріалах емпіричного дослідження розглянуто ставлення до неповносправних мешканцями різних (за чисельністю та статусом) населених пунктів Украйни за показниками «Узагальнений образ інвалідизованого», "Ставлення до інвалідизаиії близьких людей», «Ставлення до стосунків близьких людей з інвалідизованими», «Ставлення до побудови близьких стосунків з інвалідизованим», «Ставлення до можливості безпосередньої взаємодї з інвалідизованим». 3'ясовано, щуо прояви гандикапізму, як негативної соціальної установки, упередження щуодо неповносправних, більш поширені в обласних центрах, натомість у селах $i$ селищах міського типу вони практично не проявляються.

Ключові слова: соціальна установка, інвалідизована особистість, місто, село, селище міського типу, образ, моделювання, стигматизація, упередження.

В статье рассматриваются вопросы психологического анализа существующей в современном мире сочиальной установки относительно инвалидизированных ее членов. На материалах эмпирического исследования рассмотрено отношение к инвалидам жителей разных (по численности и статусу) населенных пунктов Украинь по измерительным шкалам: «Обобщенный образ инвалидизированных», «Отномение к инвалидизаџии близких людей», «Отношение к интеракциям близких людей с инвалидизированными», «Отношение к построению близких связей с инвалидизированными», «Отношение $к$ возможности непосредственного взаимодействия с инвалидизированными». Выяснено, что проявления гандикапизма, как негативной сочиальной установки, предубеждения относительно инвалидов, более распространень в областных центрах, а в селах и поселках городского типа они практически не проявляются.

Ключевые слова: сочиальная установка, инвалидизированная личность, город, село, поселок городского типа, образ, моделирование, стигматизаџия, предубеждения.

Постановка проблеми. Співіснування здорової та інвалідизованої частини соціуму було завжди, власне від початку буття самого людства. Та чи постійним було ставлення повносилих до інвалідизованих? Історія дає відповідь на це запитання - ні. Ми володіємо свідченнями про динаміку розвитку цих відношень: від вкрай негативних (Древній Рим) до помірно миролюбивих (епоха виникнення та розвитку Християнства). Річ у тім, що соціальна установка, як мотиваційний рушій, не існує в замкненому просторі, сама по собі. Вона виявляється у відповідних особистісних поведінкових актах: від співчуття та милосердя до дискримінації та фізичного знищення. Та більш руйнівної природи вона набуває в своїх інституціональних формах: знаходить вираження у законодавчих актах, що визначає іiі (установки) домінуючий, панівний характер у тій чи іншій державі, тобто набуває статусу державної політики щодо інвалідизованих. 
За даними ООН кількість інвалідизованих людей у світі - приблизно 600 млн. людей. Тобто близько 10,0 \% населення. Кількість інвалідів в Україні впродовж останніх 5 років зросла на 5,5 \% і на початок 2013 р. становила 3,2 млн. осіб, або майже 8,0 \% загальної кількості населення. У 2017 році цей показник перевищив 10\%.Військові дії сьогодення значно підвищили цю статистику (крім фізичного каліцтва, понад 80 \% учасників АТО отримують посттравматичний стресовий розлад - ПТСР, а це на сьогодні понад 300 тис. чол. Виходячи із сказаного вище досить актуальним сьогодні стає питання психології стосунків та ставлень здорової частини населення до неповносправних.

Аналіз останніх досліджень і публікацій. У сучасній науці багато уваги приділяється питанню інвалідності (Л. С. Виготський, О.Р. Лурія, Л. Й. Вассерман, Т. Парсонс, В.В. Радаєв, О.І. Шкаратан, О.Р. Ярська-Смірнова та ін.), росту інвалідизації населення, дослідженню соціально-економічних причин, механізмів та факторів, які детермінують цю проблему. Продовжує розроблятись і вдосконалюватись законодавча база, що містить закони та нормативні акти, метою яких є надання допомоги людям з особливими потребами [1]. Водночас психологія гандикапізму як суспільного явища у вітчизняній науковій традиції почала розроблятись відносно нещодавно [2]. Поняття «гандикапізм» ми тлумачимо як забобони стосовно осіб з певними відхиленнями від норми, що актуалізуються за рахунок негативних уявлень про неповносправних. Такі погляди містяться в суспільній свідомості, а також виявляються на несвідомому рівні як колективне підсвідоме (архаїчні стереотипи), які функціонують за рахунок архетипів [3].

Формулювання цілей статті. Мета статті полягає у з'ясуванні психологічних особливостей ставлення мешканців різних населених пунктів до можливих відносин близьких їм людей (членів сім’ї, родини, друзів) з інвалідизованими.

Виклад основного матеріалу дослідження. Для досягнення мети ми використали методику ситуативного моделювання ставлення до інвалідів, апробували та стандартизували iii [4]. Методика являє собою набір із 30 ситуативних завдань, спрямованих на виявлення ставлення до інвалідів. В основі побудови методики лежить проективний принцип, тобто стимульний матеріал має невизначений, нечіткий, розмитий характер, що дозволяє обстежуваному вільно проектувати на нього свої підсвідомі думки та переживання. Методика поєднує в собі принципи побудови, властиві групі проективних методик, типу «Незавершені речення» та «Закінчення розповіді», і спрямована на виявлення ставлення до інвалідів з урахуванням таких його компонентів, як когнітивний, емоційний та поведінковий. Для цього обстежуваному пропонується уявити, щоб він думав, відчував та хотів зробити в різних ситуаціях взаємодії з інвалідом. Обробка отриманих даних передбачає якісний аналіз, в процесі якого всі відповіді розподіляються за трьома критеріями: позитивне, нейтральне та негативне ставлення. При цьому окремо визначається модальність кожного 3 компонентів ставлення (когнітивного, емоційного, поведінкового). Висловлювання, що відображують позитивне ставлення до інваліда оцінюються в 1 бал; висловлювання, що дозволяють охарактеризувати ставлення до інваліда як нейтральне, чи байдуже - в 2 бала; висловлювання, що несуть негативний характер - в 3 бала. При подальшому аналізі визначається показник кожного обстежуваного шляхом виявлення середнього арифметичного, що отримується при додаванні балів, отриманих за когнітивним, емоційним та поведінковим компонентом, та діленням цієї суми на три.

Дослідження проводилось впродовж 2014-2017 року у населених пунктах Рівненської, Волинської, Київської, Запорізької та Сумської областей України. Загальна чисельність опитаних становила 570 осіб віком від 18 до 70 років різних професій та рівня освіти. Отримані емпіричні дані ми узагальнили в таблиці 1.

За шкалою «Узагальнений образ інваліда» позитивне сприйняття людини 3 обмеженими можливостями проявляється в більшій мірі в жителів села (12,3\%). У них сформоване сприятливе ставлення до інваліда, готовність при необхідності надати йому допомогу. Образ людини з функціональними обмеженнями не викликає негативних емоцій, оскільки наявна вада сприймається як ознака, що лише підкреслює своєрідність людини. При 
цьому прагнення відгородитись від інваліда, уникати контактів 3 ним не актуалізується, оскільки він не сприймається як «чужий».

Таблиця 1.

Кількісні показники різних типів ставлення до інвалідизованих

\begin{tabular}{|c|c|c|c|c|c|c|c|c|c|c|c|c|}
\hline \multirow{3}{*}{ 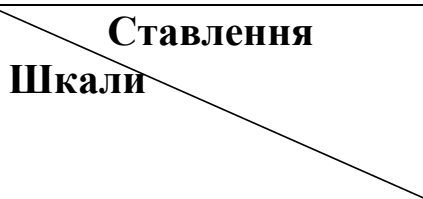 } & \multicolumn{12}{|c|}{$\begin{array}{c}\text { Показники різних типів ставлень до інвалідизованих в } \\
\text { залежності від місця проживання респондента (у\%) }\end{array}$} \\
\hline & \multicolumn{4}{|c|}{ Позитивне } & \multicolumn{4}{|c|}{ Нейтральне } & \multicolumn{4}{|c|}{ Негативне } \\
\hline & 1 & 2 & 3 & 4 & 1 & 2 & 3 & 4 & 1 & 2 & 3 & 4 \\
\hline $\begin{array}{ll}\text { узагальнений } & \text { образ } \\
\text { інвалідизованого } & \end{array}$ & 8,3 & 9,8 & 9,5 & 12,3 & 75 & 75,4 & 76,7 & 79,3 & 16,7 & 14,8 & 13,8 & 8,4 \\
\hline $\begin{array}{l}\text { ставлення до інвалідизації } \\
\text { близьких людей }\end{array}$ & 5,2 & 2,3 & 6,5 & 2,3 & 45,6 & 46,6 & 43,3 & 37,5 & 49,2 & 54,3 & 50,2 & 60,2 \\
\hline $\begin{array}{llr}\text { ставлення } & \text { до стосунків } \\
\text { близьких } & \text { людей } \\
\text { iнвалідизованим } & \\
\end{array}$ & 5,5 & 8,7 & 9,7 & 4,6 & 77,2 & 69,8 & 74,1 & 72,1 & 17,3 & 21,5 & 16,2 & 23,3 \\
\hline $\begin{array}{llr}\text { ставлення } & \text { до побудови } \\
\text { близьких } & \text { стосунків } \\
\text { iнвалідизованим } & \\
\end{array}$ & 4,2 & 6,4 & 7,2 & 4,4 & 70,4 & 70,3 & 70,6 & 76,4 & 25,4 & 23,3 & 22,2 & 19,2 \\
\hline $\begin{array}{l}\text { ставлення до можливості } \\
\text { безпосередньої взаємодії } 3 \\
\text { інвалідизованим }\end{array}$ & 16,4 & 19,2 & 15,4 & 20,2 & 75,4 & 74,4 & 77,3 & 75,5 & 8,2 & 6,4 & 7,3 & 4,3 \\
\hline
\end{tabular}

Серед мешканців селищ міського типу (СМТ) на міст обласного підпорядкування позитивне сприйняття образу інваліда проявляється в меншої кількості осіб $(9,8$ \% та 9,5 \%). Це вказує на їх нездатність об'єктивно оцінити індивідуальні особливості інваліда, оскільки в їхній свідомості панують негативні стереотипи, що призводить до викривлення сприйняття. Найменша кількість опитаних (8,3\%), яким притаманне сприятливе ставлення до незнайомого інваліда була виявлена серед представників обласного центру. Це свідчить про переважання нейтральних та негативних оцінок образу інваліда. Такі особи не здатні вийти за межі стереотипного бачення людини з обмеженими можливостями, схильні до проявів стигматизації, дискримінації та упередженого ставлення до неї. Така ж тенденція зберігається і при аналізі особливостей негативного сприйняття інваліда. Найбільша кількість респондентів (16,7\%), яким притаманне негативне ставлення до людей 3 обмеженими можливостями була виявлена серед жителів обласного центру, що свідчить про більшу вираженість гандикапізму в великих містах. Він проявляється у вигляді проявів ворожості та агресивної поведінки щодо інвалідів, які розглядаються як неповноцінні люди, наділені низьким рівнем інтелекту, здібностей та можливостей, яким притаманні такі особистісні властивості, як емоційна нестабільність, плаксивість, дратівливість, нав'язливість тощо. Серед мешканців СМТ та міст обласного підпорядкування практично однакова кількість опитаних (14,8 \% та 13,8 \%) схильна до негативного сприйняття інваліда, яке відбувається за фобічним типом, тобто набуває форми гандифобізму [5], що проявляється у виникненні почуття тривоги, дискомфорту та страху в ситуації зіткнення 3 інвалідом, що в свою чергу заважає формуванню об'єктивного та адекватного образу інваліда в очах здорової людини. Серед жителів сіл кількість осіб, що негативно сприймає інваліда найменша $(8,4$ \%), що вказує на переважання в них такого виду сприйняття людини з обмеженими можливостями, що дозволяє формувати з нею активну взаємодію.

За шкалою «Ставлення до інвалідизації близьких людей» виявлено, що слабко виражена реакція на набуття значущою людиною вади притаманна $6,5 \%$ осіб, що проживають в містах обласного підпорядкування. Це вказує на те, що такі респонденти готові змиритись з фактом інвалідизації близької людини, не сприймають це як трагедію, оскільки вірять в можливості особистості до адаптації, пристосування до нових умов та ії 
здатності жити повноцінним життям не зважаючи на наявність дефекту. Серед мешканців обласного центру було виявлено дещо меншу кількість опитаних, що демонструють слабко виражену реакцію на змодельовану ситуацію. Специфіка їх сприйняття інвалідизації близької людини пояснюється вірою в можливості медицини, тобто інвалідність не сприймається як фатальний чинник, особистість готова докласти значних зусиль, щоб повернути значущу для себе людину до звичного життя. В ході дослідження було виявлено, що серед мешканців сіл та СМТ 2,3 \% осіб не схильні до бурхливого емоційного реагування на представлену ситуацію. Такі оптанти сприймають інвалідизацію близької людини як подію, що в значній мірі вплине на якість життя родини, що зумовлено недостатньою якістю медичних послуг, які доступні сільськими жителям, територіальною віддаленістю реабілітаційних центрів, що забезпечили б швидку адаптацію до умов, зумовлених наявністю вади, а також архітектурною непристосованістю громадських місць до потреб інваліда.

При аналізі представленості бурхливого реагування на ситуацію інвалідизації близької людини помітно, що найбільш вираженою (60,2 \%) вона є серед мешканців сіл. Незважаючи на позитивне сприйняття образа інваліда в цілому такі респонденти схильні оцінювати ситуацію набуття вади як критичну, що зумовлено перерахованими вище причинами. Такий спосіб реагування властивий також мешканцям СМТ (54,3\%), що зумовлено специфікою їх життя та значними фізичними навантаженнями, які повинна виконувати людина в процесі здійснення сільськогосподарської та побутової діяльності, що і пояснює сприйняття інвалідизації близької людини як значної проблеми. Досить значна кількість осіб використовує таку модель поведінки і серед представників обласного центру $(49,2 \%)$ та міст обласного підпорядкування (50,2\%), що вказує на переважання цієї когнітивної моделі оцінки заданої ситуації в респондентів в цілому.

Показники за шкалою «Ставлення до стосунків близьких людей з інвалідами» також різняться. Найбільша кількість осіб, що позитивно сприймає можливість побудови значущою для неї людиною тісних стосунків з інвалідом була виявлена серед мешканців міст обласного підпорядкування $(9,7 \%)$. Такі оптанти не виступають проти дружби та побудови більш тісних стосунків близької людини з особою з функціональними обмеженнями, стверджуючи, що інвалідність не є перешкодою до нормального життя, самореалізації в професійній чи іншій діяльності. Вони сприймають інваліда перш зам все як особистість, акцентуючи увагу на його індивідуальних властивостях, а не на фізичному дефекті. Дещо менша кількість опитуваних $(8,7$ \%), що готові підтримати близьку людину в іiї прагненні до тісних контактів 3 інвалідом була виявлена серед жителів СМТ. При цьому допустимими стосунками вважаються дружні, тоді як можливість одруження з інвалідом викликає несхвалення. Ще менша кількість людей, що позитивно сприймають змодельовану ситуацію була виявлена серед представників обласного центру (5,5\%) та сіл (4,6 \%), що пов'язано з переважанням позиції невтручання, та переконанням, що близька людина сама в змозі визначити 3 ким контактувати, а з ким ні.

Негативне сприйняття даної ситуації притаманне 23,3 \% мешканцям сіл та 21,5\% представників СМТ, що пов'язано з умовами життя в селі, де фізична праця виходить на перший план. Відповідно, людина з обмеженими можливостями розцінюється як нездатна до ефективного виконання багатьох функцій, а одруження близької для оптанта людини з нею розглядається як фактор, що призведе до зниження рівня життя родини в цілому. Однак ситуація побудови дружніх стосунків в більшості випадків розцінюється позитивно. Якісний аналіз результатів показав, що мешканці обласного центру, серед яких 17,3 \% осіб, негативно реагують на змодельовану ситуацію, проявляють ознаки гандикапності [6], оскільки причиною, що спонукає їх до недопущення близьких контактів значущої людини з інвалідом $€$ акцентуація уваги на його неповноцінності, нездатність та небажання об'єктивно оцінити особистісні властивості, переважання зверхньої позиції та ставлення до нього як до людини «другого гатунку», що не заслуговує на спілкування зі здоровими людьми. Серед респондентів 3 міст обласного підпорядкування було виділено 16,2 \% осіб, що негативно оцінюють перспективи такої взаємодії. Виявлено, що причиною такого ставлення є почуття тривоги та неспокою, наявність фрустрації та астенічних емоцій при взаємодії з інвалідом. 
Цей стан приписується і близьку людину, внаслідок чого ізоляція від інваліда розглядається як механізм захисту її від негативних емоцій.

За шкалою «Ставлення до побудови близьких стосунків з інвалідом» було виявлено 7,2 \% жителів міст обласного підпорядкування, які допускають можливість побудови тісних стосунків 3 інвалідом. Такі респонденти здатні до адекватної оцінки людини 3 функціональними обмеженнями, визначення ऑї особистісних якостей, сприймання не як представника групи інвалідів, а як повноцінної людини зі своїми потребами та переживаннями. Дещо менша кількість осіб (6,4 \%), які позитивно сприймають можливість побудови близьких стосунків з інвалідом була виявлена серед мешканців СМТ. При цьому сприятливо оцінювалась можливість стосунків з людиною, що має незначні фізичні вади та зберігає працездатність. Практично однакова кількість мешканців обласного центру (4,2 \%) та сіл $(4,4 \%)$ допускає можливість побудови тісних стосунків 3 інвалідом при наявності відповідних почуттів. Негативна оцінка представленої ситуації переважає у мешканців обласного центру $(25,4$ \%). Такі оптанти проявляють щодо інваліда відкриту ворожість, вербальну агресію, підкреслюють його неповноцінність, застосовують стосовно нього різні форми дискримінації. Думка про можливість встановлення близьких стосунків 3 інвалідом викликає у таких респондентів обурення, роздратування та супротив. Незначна відмінність показників простежується в мешканців СМТ (23,3\%) та міст обласного підпорядкування (22,2 \%). Ці оптанти не бажають зв'язувати своє життя з інвалідами та уникають взаємодії 3 ними, не проявляючи однак відкритої ворожості. Серед мешканців сіл 19,2 \% осіб схильні ухилятись від побудови близьких стосунків з інвалідом, що зумовлено особливими умовами їхнього життя.

Аналіз показників за шкалою «Ставлення до можливості безпосередньої взаємодії 3 інвалідом» дозволив виявити, що позитивно оцінюють можливість встановлення контактів 3 людьми 3 функціональними обмеженнями 20,2\% осіб, що проживають в селах та $19,2 \%$ респондентів, що є мешканцями СМТ. Цей досить високий показник пояснюється більш тісними контактами між жителями села в цілому, та сприйманням інваліда як частини спільноти, а не як представника меншини, до якої зазвичай відносять людину 3 функціональними обмеженнями мешканці великих міст. Серед представників обласного центру позитивно оцінює перспективу такої взаємодії 16,4 \% осіб, а серед мешканців міст обласного підпорядкування - 15,4\%. При цьому контакти зазвичай носять формальний характер та зумовлюються необхідністю взаємодії. Негативно сприймають можливість безпосередньої взаємодії з інвалідом 8,2% мешканців обласного центру. Їх гандикапність проявляється в прагненні принизити інваліда в процесі інтеракції, проявах зневаги до нього. Серед жителів міст обласного підпорядкування було виявлено 7,3 \% осіб, що прагнуть уникати взаємодії 3 інвалідом через схильність до гандифобних реакцій, що унеможливлюють побудову гармонійних контактів. Натомість, серед мешканців сіл лише 4,3 \% опитуваних схильні до ізоляції від інваліда, що зумовлюється конкретною ситуацією взаємодії та індивідуальними рисами людини з обмеженими можливостями.

Висновки дослідження і перспективи подальших розвідок у даному напрямку. Прояви гандикапізму, як негативної соціальної установки, упередження щодо неповносправних, більш поширені в обласних центрах, натомість у селах і селищах міського типу вони практично не проявляються. Перспективні напрями подальших досліджень ми пов'язуємо із розробкою дієвих методів впливу та корекції негативного ставлення до людей 3 особливими потребами.

\section{Список використаних джерел}

1. Законодавство про інвалідів. Вся законодавча база. Національна асамблея людей $з$ інвалідністю України [Електронний ресурс]. - Режим доступу: http: naiu.org.ua/zakonodavstvo/

2. Ставицький О. О. Гандикапізм: психологічний аналіз : монографія / О. О. Ставицький. - Рівне : Принт Хаус, 2013. - 352 с. 
3. Корсини Р. Энциклопедия психологии [Электронный ресурс]/ Р. Корсини, А. Ауэрбах. - Режим доступа : http: //enc-dic.com/enc_psy/Gandikap-6053.html.

4. Ставицький О. О. Психологія проявів гандикапізму та їх регуляція : дис. ... д-ра психол. наук : 19.00.01 - загальна психологія. Історія психології / О. О. Ставицький. - Київ, 2014. $-595 \mathrm{c}$.

5. Ставицкий О. А. Психологическая модель гандифобности [Электронный ресурс] / О. А. Ставицкий // Перспективы науки и образования. - 2014. - № 1 (7). - С. 211-215. Режим доступа : http://psejournal.wordpress.com.

6. Stavitsky O. A. Psychological model handicapnost' / O. A. Stavitsky // Austrian Journal of Humanities and Social Sciences : Scientific journal. - 2014. - № 1 (January-February) ; Vol. 1. - P. 301-310.

\section{References}

1. Zakonodavstvo pro InvalIdIv. Vsya zakonodavcha baza. NatsIonalna asambleya lyudey z InvalIdnIstyu UkraYini. [Elektronniy resurs] - Rezhim dostupu: http: naiu.org.ua/zakonodavstvo/. Nazva z ekranu.

2. Stavitskiy O. O. GandikapIzm: psihologIchniy analIz : monografIya / O. O. Stavitskiy. RIvne: Print Haus, 2013. - $352 \mathrm{~s}$.

3. Korsini R. Entsiklopediya psihologii [Elektronnyiy resurs] / R. Korsini, A. Auerbah. Rezhim dostupa : http: //enc-dic.com/enc_psy/Gandikap-6053.html. - Nazvanie s ekrana.

4. Stavitskiy O. O. PsihologIya proyavIv gandikapIzmu ta Yih regulyatsIya: dis.. na zdobuttya nauk. stupenya doktora psihol. nauk : spets. 19.00.01 «Zagalna psihologIya. Istorlya psihologIYi» / O. O. Stavitskiy. - Київ, 2014. - 595 s.

5. Stavitskiy O. A. Psihologicheskaya model gandifobnosti [Elektronnyiy resurs] / O. A. Stavitskiy // Perspektivyi nauki i obrazovaniya. - 2014. - № 1 (7). - S. 211-215. - Rezhim dostupa : http://psejournal.wordpress.com.

6. Stavitsky O. A. Psychological model handicapnost' / O. A. Stavitsky // Austrian Journal of Humanities and Social Sciences : Scientific journal. - 2014. - № 1 (January-February) ; Vol. 1. P. 301-310.

\section{O. O. Stavitskyi, O. G. Stavitska. PSYCHOLOGICAL ANALYSIS OF SOCIAL INSTALLATION TO DISABLED PEOPLE IN DEMOGRAPHIC PLANE.}

The article is devoted to the psychological analysis of the installation in the modern society in relation to its disadvantaged members. On the materials of the empirical research the attitude towards the disabled people of different (by number and status) of the settlements of Ukraine according to the indicators "Generalized image of the disabled", "Attitude towards the disability of close people", "Attitude to the relations of close people with the disabled", "Attitude to the construction of relatives relationships with the disabled", "Attitude to the possibility of direct interaction with the disabled".

Positive perception of a person with disabilities is manifested more to the inhabitants of the village. They have formed a favorable attitude towards the disabled, readiness to help him if necessary. The image of a person with functional limitations does not cause negative emotions, because the physical disability is perceived as a sign that only emphasizes the peculiarity of man.

The largest number of respondents who have a negative attitude towards people with disabilities were found among the residents of the regional center, which indicates a greater degree of handicapism in large cities. It manifests itself in the form of manifestations of hostility and aggressive behavior in relation to persons with disabilities that are considered as inferior people, endowed with a low level of intelligence, abilities and opportunities, which are characterized by such personal qualities as emotional instability, tearfulness, irritability, obsession, etc.

Key words: social setting, disabled person, city, village, urban type, image, modeling, stigmatization, prejudice. 